\title{
HERMENEUTIKA AL-QUR'AN DALAM PERSPEKTIF FARID ESSACK
}

\author{
Elya Munfarida*
}

\section{Abstract}

Reception hermeneutic toward Al-Qur'an in Farid Essack perspective is not only able to accommodate the bistory of texts but also to give space for readers to 'bave dialogues' with text based on social contexts. This approach is applied as a to get objective interpretation especially in South Africa with its characteristic (rasism, economic exploitation, etc).

Kata kunci: Hermeneutika, resepsi, subyektifitas pembaca.

\section{A. Pendahuluan}

Al-Qur'an diturunkan kepada manusia tidak dalam ruang kosong, tapi dalam situasi kongkrit kemanusiaannya. Kehadirannya merupakan respon terhadap berbagai kondisi sosio-kultural yang dihadapi oleh masyarakat Arab saat itu sebagai penerimanya. Dialog yang intensif antara al-Qur'an sebagai teks dan masyarakat Arab dengan realitas historisnya sebagai konteks, menampilkan sisi historisitas al-Qur'an, disamping sisi normativitas yang termanifestasikan dalam ajaran-ajaran dasarnya yang mampu mentransendensikan dirinya melampaui ruang dan waktu. Oleh karena itu,

- Penulis adalah dosen tetap jurusan Dakwah STAIN Purwokerto. 


\section{Elya Munfarida}

untuk memahaminya, menurut Komaruddin Hidayat, diperlukan double analogi, yakni analogi konseptual antara the world of human being serta the world of God dan analogi historis antara dunia komunitas Arab sebagai penerima wahyu dan dunia Muslim kontemporer dalam ruang dan waktu yang sama sekali berbeda. ${ }^{1}$

Historisitas al-Qur'an inilah yang menjadikannya mampu menjadi referensi umat Islam selama berabad-abad. Kehadirannya telah menciptakan diskursus keislaman yang bergerak secara sentrifugal dan sentripetal. Gerak sentrifugal merepresentasikan bahwa teks al-Qur'an memiliki daya dorong yang luar biasa bagi umat Islam untuk menafsirkan dan mengeksplorasi maknanya sehingga terjadi pengembaraan intelektual (intellectual journey). Sementara gerak sentripetal menggambarkan bahwa meskipun berbagai diskursus keilmuan Islam telah berlangsung selama berabad-abad dan telah memproduksi berbagai karya tafsir, namun upaya untuk merujuk alQur'an juga semakin kuat. ${ }^{2}$ Akumulasi dialektika al-Qur'an yang tercermin dalam dialog sirkular antara dimensi normativitas dan historisitasnya, menurut Wilfred Cantwell Smith, telah mengkonstruksikan sebuah tradisi kumulatif Islam, ${ }^{3}$ yakni konstruksi religiohistoris yang berkembang secara dinamis seiring dengan perkembangan masyarakat Islam.

Dialektika yang intens antara al-Qur'an dengan realitas sosiokultural penerimanya di atas, juga merepresentasikan adanya unsur transformatif dan liberatif al-Qur'an. Dalam konteks ini, seperti dinyatakan Moeslim Abdurrahman, salah satu fungsi penting dari kehadiran Islam adalah sikap korektif terhadap berbagai distorsi sejarah yang menyimpang dari nilai-nilai kemanusiaan. Distorsi inilah yang disebut sebagai bentuk dehumanisasi yang dalam bahasa alQur'an ditengarai sebagai "proses kemusyrikan". "Kemusyrikan"

\footnotetext{
${ }^{1}$ Komaruddin Hidayat, Memabami Babasa Agama (Jakarta: Paramadina, 1996), hal. 9.

${ }^{2}$ Ibid., hal. 15.

${ }^{3}$ Wilfred Cantwell Smith, The Meaning and End of Religion (Minneapolis: Fortress Press, 1991), hal. 156-157.

${ }^{4}$ Moeslim Abdurrahman, Islam Yang Memibak (Yogyakarta: LKiS, 2005), hal. 1.
} 
Arab jahiliyyah yang berporos dari pandangan dunianya (world view) yang menjadikan dunia (inner worldly) sebagai orientasi utama kehidupannya dan memarginalkan Tuhan dalam konsep hidupnya, telah melahirkan berbagai hegemoni dan eksploitasi kemanusiaan baik dalam aspek sosial, politik, budaya, maupun ekonomi. ${ }^{5}$

Berbagai perubahan penting telah dilakukan Islam dalam berbagai aspek kehidupan manusia, baik dalam bidang teologis, sosial, politik dan ekonomi. ${ }^{6}$

Sejarah peradaban Islam menjadi saksi berbagai transformasi yang dilakukannya dengan mendekonstruksi sistem pandangan hidup yang bersifat worldly-oriented menjadi God-oriented, yang kemudian berimplikasi terhadap transformasi berbagai manifestasi kulturalnya. Kemapanan kultural dan struktural yang menghasilkan praktekpraktek eksploitasi sosial ekonomi ditentang karena menyimpang dari nilai-nilai kemanusiaan. Keberpihakan terhadap kaum lemah (mustad'afin) dan penentangan praktek yang hegemonik dan eksploitatif, misalnya riba, pembebasan budak, dan sebagainya, merupakan manifestasi unsur liberatif dan transformatif Islam.

Dalam perjalanan sejarah, unsur transformatif liberatif alQur'an ini, mengalami marginalisasi karena dominasi interpretasi mistiko-teologis terhadap ayat-ayat al-Qur'an. Filsafat Yunani, seperti diungkapkan Asghar Ali Engginer, di samping memberi manfaat besar bagi perkembangan pemikiran spekulatif, juga telah menyibukkan umat Islam pada pembicaraan teologis yang bersifat metafisis

${ }^{5}$ Keterangan lebih jauh tentang pandangan hidup masyarakat Arab jahiliyyah, lihat Khalil Abdul Karim, Hegemoni Quraisy: Agama, Budaya, Kekuasaan (Yogyakarta: LKiS, 2002), hal. $185-333$.

${ }^{6}$ Untuk melihat berbagai transformasi Islam dalam berbagai konsep kehidupan masyarakat Arab jahiliyyah, maka wawasan rerkait dengan realitas kebudayaan serta pandangan hidup masyarakat Arab pra Islam menjadi penting. Beberapa buku yang ditulis oleh Khalil Abdul Karim dapat memberikan gambaran obyektif kondisi masyarakat Arab serta beberapa transformasi konsep-konsepnya dalam Islam, yakni Hegemoni Quraisy: Agama, Budaya, Kekuasaan, (Yogyakarta: LKiS, 2002), Negara Madinab: Politik Penaklukan Masyarakat Suku Arab, (Yogyakarta: LKiS, 2005), dan Syari'ab: Sejarab Perkelabian Pemaknaan (Yogyakarta: LKiS, 2003). 


\section{Elya Munfarida}

semata, ${ }^{7}$ sehingga teologi yang berkembang lebih bersifat teosentris daripada antroposentris.

Kegelisahan yang sama juga dirasakan oleh Farid Essack ketika mengamati keberagamaan umat Islam di Afrika Selatan. Menguatnya teologi akomodasi (accomodation theology) yang cenderung berpihak pada status quo dengan ideologi rasisme, kapitalisme dan totaliarianismenya, berperan besar dalam memarginalkan dimensi liberatif Islam. Padahal, menurut Essack, teologi yang seharusnya dikembangkan dalam konteks Afrika Selatan justru sebaliknya, yakni teologi pembebasan (liberation theology). ${ }^{8}$ Dalam teologi ini, agama dijadikan sebagai basis ideologis praksis, untuk membebaskan masyarakat Afrika Selatan dari berbagai bentuk ketidakadilan, opresi, diskriminasi, dan eksploitasi.

Model teologi pembebasan ini, mendorong Farid Essack untuk mencari bentuk hermeneutika al-Qur'an, sebagai alat untuk menggali dimensi transformatif liberatif dalam ayat-ayat al-Qur'an sebagai solusi atas berbagai persoalan sosial yang dihadapi umat Islam di Afrika Selatan. Elaborasi yang mendalam terhadap pemikiran Farid Essack ini, penting guna mengetahui bagaimana pergumulan serta respon teologis yang diberikan umat Islam Afrika Selatan dalam konteks problem sosial politik yang dihadapi. Kajian ini, pada akhirnya berujung pada persoalan bagaimana bentuk hermenutika al-Qur'an yang dikembangkan Farid Essack, dalam merespon realitas sosial politik masyarakatnya.

\section{B. Sekilas Tentang Farid Essack}

Farid Essack tumbuh dan berkembang di Bonteheuwel, sebuah kotapraja yang dihuni oleh masayarakt kulit berwarna di flats Cape. Dengan adanya kebijakan the Group Areas Acts, tempat ini wilayah

\footnotetext{
'Asghar Ali Enggineer, Islam dan Teologi Pembebasan, Terj. Agung Prihantoro (Yogyakarta: Pustaka Pelajar, 1999), hal. ix-x.

${ }^{8}$ Farid Essack, Qur'an, Liberation \& Pluralism: an Islamic Perspectives of Interreligious Solidarity Against Oppression (England: Oneworld, 1977), hal. 7-8.
} 
yang khusus diperuntukkkan bagi warga kulit berwarna. Hukum Apartheid yang diresmikan pada tahun 1952, telah menyisihkan mereka di wilayah-wilayah yang tandus dan kurang produktif. Diskriminasi rasial ini semakin memarginalkan mereka baik secara sosial, politik, maupun ekonomi. ${ }^{9}$

Sejak kecil, Essack sudah memiliki perhatian besar terhadap realitas sosial masyarakatnya yang menderita kemiskinan dan marginalisasi sebagai akibat dari implementasi hukum Aparthid, eksploitasi ekonomi, hegemoni sistem patriarkhi dan rasisme. Ketika berumur sembilan tahun, ia sudah terlibat dalam organisasi Tablighi Jama'ah, sebuah organisasi revivalis Muslim internasional. Dia juga pernah ditangkap oleh polisi, ketika masih sekolah, terkait dengan keterlibatannya di National Youb Action dan South African Black Scholars Association. Kedua organisasi ini memiliki komitmen terhadap perubahan sosial politik dan bertempat di gedung Christian Institute sebelum dilarang pada tahun $1973 .{ }^{10}$

Setelah menyelesaikan sekolahnya, ia mengikuti training teologi di Pakistan selama 9 tahun dan menemukan beberapa kesamaan antara kondisi masyarakatnya dengan masyarakat Pakistan. Diskriminasi dan penindasan terhadap kelompok minoritas Hindu dan Kristen; gap antara teologi konservatif dan teologi progresif; dan opresi terhadap perempuan dalam masayarakat Islam merupakan beberapa problem yang terjadi di Pakistan. Beberapa diskusi yang dilakukannya dengan The Student Christian Movement, yang kemudian dinamai Breakthrough, mempertegas kesadarannya betapa sulitnya hidup di tengah-tengah komunitas yang tidak adil dan eksploitatif. ${ }^{11}$ Pengalaman-pengalaman selama di Pakistan semakin meneguhkan komitmennya untuk mengadvokasi kelompok yang tertindas dengan berupaya membebaskannya dari sistem-sistem yang hegemonik dan eksploitatif.

\footnotetext{
${ }^{9}$ Ibid., hal. 2.

${ }^{10}$ Ibid., hal. 3-4.

1 Ibid., hal. 5
} 


\section{Elya Munfarida}

Tahun 1983, menandai satu periode resistensi kolektif dari masyarakat Afrika Selatan lintas agama, dengan mengisolasi dirinya secara intensif dari struktur Apartheid dan menentang konstitusi yang rasial sebagai langkah awal dalam perjuangan untuk memperoleh kebebasan. Pada tahun 1984, bersama dengan tiga rekannya, Essack mempelopori berdirinya the Call of Islam, sebuah organisasi yang kemudian memiliki peran signifikan dalam perjuangan pembebasan di Afrika Selatan. Organisasinya ini juga berafiliasi dengan United Democratic Front (UDF), sebuah gerakan pembebasan yang paling aktif dan memiliki kekuatan mobilisasi secara nasional yang bergerak dalam perjuangan melawan Apartheid, ketidaksetaraan gender, berbagai ancaman sosial, serta membangun solidaritas antar agama. ${ }^{12}$

Selain itu, ia juga terlibat dalam beberapa organisasi lain, seperti the Organization of People Against Sexism dan the Cape Against Racism. Pada awal tahun 1997, ia ditunjuk sebagai ketua Komite Kesetaraan Gender oleh Presiden Nelson Mandela. Dia juga bergabung dengan beberapa organisasi independen sebagai anggota kehormatan, misalnya the Community Development Resources Association, the AIDS Treatment Action Campaign, National Public Radio, dan the Muslim Peace Fellowship. Saat ini bersama dengan Paul Knitter, ia mengkampanyekan pluralisme religius untuk mencapai keadilan. ${ }^{13}$

\section{Diskursus Pemikiran Islam di Afrika Selatan}

Realitas diskriminasi dan opresi sebagai implikasi penerapan sistem Apartheid di Afrika Selatan telah memunculkan berbagai respon teologis. Agama memiliki peran penting dulam mengkonstruksi respon umat Islam terhadap keseluruhan struktur sosial Afrika Selatan yang dibangun di atas fondasi sistem Apartheid. Dalam kondi-

${ }^{12}$ Ibid., hal. 6.

${ }^{13}$ Dadi Darmadi, "Memahami Farid Essack," dalam Farid Essack, On Being A Muslim: Menjadi Muslim Di Dunia Modern, terj. Dadi Darmadi \& Jajang Jahroni Jakarta: Erlangga, 2002), hal. xv-xvi. 
si ini, sebagaimana dikatakan Essack, agama menjadi wilayah yang diperebutkan (contested territory), ${ }^{14}$ karena masing-masing kelompok cenderung menjadikan masing-masing kitab sucinya sebagai basis argumentasi, bahkan kepentingan yang berbeda dan kontradiktif dapat mengajukan referensi tekstual yang sama.

Dalam konteks opresi, agama dalam pandangan Essack, akan memenuhi salah satu dari dua peran, yakni mendukung struktur dan institusi opresi atau menjalani fungsinya dalam perjuangan untuk kebebasan. Kedua opsi peran ini, akan membentuk ekspresi teologi yang berbeda dan pada gilirannya akan menentukan posisi politik yang diambil. Secara garis besar, respon teologis yang terbentuk berdasarkan kedua peran agama di atas dapat diklasifikasikan dalam dua bentuk. Pertama, teologi akomodasi yang berupaya mengakomodasi dan menjustifikasi status quo dengan politik rasisme, kapitalisme, dan totalitarianismenya. ${ }^{15}$ Meskipun keberpihakannya tidak dilakukan secara eksplisit, namun penolakan kelompok konservatif sebagai wakil teologi akomodasi, untuk berperan secara aktif dalam praksis politik untuk menentang kebijakan-kebijakan rezim Apartheid dan lebih mengedepankan kesalehan personal, secara implisit mengindikasikan legitimasinya terhadap kekuasaan yang ada.

Dengan menggunakan tiga peristiwa penting yang terjadi di Afrika Selatan, yakni pemilihan parlemen tiga majelis (kulit berwarna, kulit putih, dan India), tudingan bid'ah terhadap kelompok-kelompok radikal, serta kecaman terhadap orang-orang yang berpartisipasi dalam politik anti Apartheid, Ebrahim Moosa mengganggap kelompok konservatif memiliki keengganan untuk mengkritik berbagai kebijakan politik pemerintah Apartheid, dengan tidak mengeluarkan statemen politis yang mengecam sistem parlementer tiga majlis yang justru semakin memperkuat sistem Apartheid. Oposisi terhadap kelompok radikal dan tuduhan melakukan bid'ah terhadapnya dan karenanya

\footnotetext{
${ }^{14}$ Essack, Qur'an, hal. 6.

${ }^{15}$ Ibid., hal. 7.
} 


\section{Elya Munfarida}

harus dikeluarkan dari komunitas Islam, semakin meneguhkan sikap apolitis kelompok ini yang berimplikasi memapankan status quo. ${ }^{16}$

Relasi antara radikal Islam dan Syi'ah, muncul dalam pemikiran konservatif, karena menurut mereka, revolusi Iran tahun 1979 telah menginspirasikan bentuk gerakan progresif yang ditempuh oleh kelompok radikal tersebut. Meskipun pengaruh spirit revolusi teologis Iran terhadap gerakan radikal tidak dinafikan, namun wacana ini, tak pelak lagi menghadirkan kembali polemik sektarian antara Sunni dan Syi'ah dalam konteks Afrika Selatan. Bagi Sunni, seperti dinyatakan oleh Enayat, sejarah merupakan gerakan menjauh dari (away from) kondisi ideal, sementara bagi Syi'ah, sejarah adalah gerakan menuju (towards) kondisi ideal. ${ }^{17}$ Kedua gerakan ini, away from dan towards, akan mempengaruhi pandangan hidup orang Islam dan berimplikasi terhadap pemikiran dan praktek politiknya. Dengan kerangka ini, maka oposisi radikal terhadap pemerintah diambil sebagai tindakan praksis untuk membangun sejarah yang lebih baik. Sementara sikap apolitis dan pasif terhadap status quo, dianggap sebagai tindakan penolakan menciptakan sejarah dengan mengafirmasi kebijakan-kebijakan politik penguasa atau tidak terlibat dalam politik praktis.

Bentuk teologi kedua adalah teologi pembebasan (liberation theology), yakni teologi yang terlibat secara praksis dalam perjuangan untuk meraih kebebasan. Dalam teologi ini, ajaran-ajaran agama dijadikan sebagai dasar teologis pembebasan kaum yang tertindas dan yang terpinggirkan dari berbagai bentuk eksploitasi kemanusiaan. Di Afrika Selatan, teologi pembebasan diartikulasikan oleh beberapa tokoh dan organisasi yang mengakui adanya dosa atas sikap diam dan pasif dalam menghadapi praktek opresi dan eksploitasi. ${ }^{18}$

${ }^{16}$ Ebrahim Moosa, "Muslim Conservatism in South Africa", in Journal of Theology for Southern Africa 69 (December 1989), p.76-77, yang diakses di http://web.uct.ac.za/depts/ ricsa/tre/¡69moosa.htm, pada tanggal 20 Juli 2007.

${ }^{17}$ Ibid.

${ }^{18}$ Essack, Qur'an, hal. 8. 
Revolusi Iran memberikan kesadaran kaum Muslim di Afrika Selatan bahwa Islam dapat dijadikan basis ideologis praksis yang relevan dengan konteks mereka. Gerakan politik praksis pada gilirannya menjadi cara terbaik untuk mendekonstruksi dominasi dan hegemoni pemerintah Apartheid. Dengan kata lain, struktur sosiopolitik yang menindas tidak hanya dilawan secara kultural tapi terutama secara struktural, sehingga Islam revolusioner sebagai manifestasi gerakan struktural, menjadi opsi utama generasi muda Muslim Afrika Selatan dalam perjuangan politiknya.

Di antara kedua ekspresi teologi di atas, Farid Essack lebih memihak bentuk teologi kedua, teologi pembebasan, karena menurutnya iman harus didiwujudkan baik secara personal maupun sosial. Artinya, kepekaan sosial terhadap realitas yang dihadapi komunitasnya serta tanggung jawab sosial dengan berupaya mengatasi problem-problem yang ada, menjadi ukuran keimanan seseorang. Selain itu, konsekuensi peran manusia sebagai khalifah mengharuskannya berpartisipasi secara aktif dalam menciptakan sejarah, di mana nilai-nilai kemanusiaan harus dijadikan landasan dasarnya. Oleh karenanya, orang Islam harus menjadi subyek sejarah, bukan hanya sebagai obyek sejarah, melalui partisipasi kreatif dalam melakukan transformasi sosial menuju masyarakat yang adil dan humanis. Dengan kata lain, menurut Essack, yang dibutuhkan dalam konteks Afrika Selatan adalah Muslim intervensionis yang memiliki kesadaran untuk mentransformasikan lingkungannya dan memberikan kontribusi bagi penciptaan dunia baru. ${ }^{19}$

\section{Hermenutika Resepsi: Pencarian Makna dalam Konteks Pembaca}

Dalam konteks Afrika Selatan, hermeneutika sebagai seni dan metode penafsiran teks, menawarkan suatu perspektif baru yang mencerahkan dan menjanjikan bagi suatu pencarian makna baru teks

${ }^{19}$ Essack, On Being A Muslim, hal. 124-126. 


\section{Elya Munfarida}

al-Qur'an, yang sesuai dengan konteks perjuangan mereka melawan berbagai penindasan. Hegemoni penafsiran teks religius yang didominasi oleh kelompok religius tertentu, justru telah melegitimasi kemapanan kekuasaan yang ada. Kondisi ini semakin menyudutkan posisi umat Islam yang nota bene menjadi salah satu kelompok yang tertindas. Pencarian makna-makna baru dari teks al-Qur'an, menjadi persoalan yang sangat penting sebagai dasar teologis untuk membebaskan masyarakat Afrika Selatan secara umum dari belenggu represi pemerintah Apartheid.

Hermeneutika didefinisikan Carl Braaten sebagai ilmu yang merefleksikan bagaimana suatu teks atau peristiwa dalam masa dan budaya lampau dipahami dan bermakna secara eksistensial dalam situasi sekarang. Hermeneutika, dengan demikian menurut Rudolf Bultman, merupakan suatu kajian yang berupaya menjembatani gap atau kesenjangan antara masa lalu dan masa kini. ${ }^{20}$ Dalam konteks al-Qur'an, hermeneutika diaplikasikan untuk menghadirkan teks alQur'an yang merupakan produk historis dan kultural pada masa lalu, guna memberikan petunjuk bagi umat Islam kontemporer dalam menghadapi berbagai problem yang dihadapi.

Hermenutika mengasumsikan bahwa setiap penafsir akan membawa ekspektasinya ketika berhadapan dengan teks yang akan ditafsirkan. Oleh karenanya, tuntutan obyektifitas penafsiran dengan menanggalkan subyektifitas penafsir dalam proses penafsiran adalah sesuatu yang absurd dan teks akan bisu tanpa kehadiran prapemahaman dan subyektifitas penafsir. ${ }^{21}$

Hans-George Gadamer, seorang tokoh penggagas hermenutika filosofis, berperan besar mengembangkan peran subyektifitas penafsir ini. Menurutnya, penafsiran selalu merupakan proses sirkular, di mana teks masa lalu hanya dapat dipahami dari sudut pandang dan situasi kekinian kita (our historical present). Penafsir dan teks senantiasa terikat oleh konteks tradisinya masing-masing, sehingga seorang

${ }^{20}$ Essack, Qur'an, hal. 51.

${ }^{21}$ Ibid. 
penafsir, sadar atau tidak sadar, selalu mempunyai 'pra-paham' tertentu terhadap teks yang ingin ditafsirkan. Penafsiran hanya dimungkinkan melalui the fusion of horizons, yakni mempertemukan 'prapaham' penafsir dengan cakrawala makna yang dikandung teks. ${ }^{22}$ Konsekuensinya, penafsiran sebuah teks bukanlah sebuah proses reproduksi makna, tetapi produksi makna baru yang dihasilkan dari interaksi teks dengan situasi kontemporer penafsir. Karena bersifat produktif, maka tidak ada repetisi makna.

Berdasarkan kerangka teoritik di atas, Farid Essack mengungkapkan bahwa meskipun secara definitif istilah hermenutika tidak ada dalam kajian keilmuan Islam, namun makna dan metode operasionalisasinya secara implisit telah berkembang dalam diskursus Islam. Alasannya adalah: ${ }^{23}$

1. Problem-problem hermeneutika selalu dialami secara aktif, meskipun secara tematik tidak ditampilkan, yang dalam konteks Islam terlihat jelas dalam diskusi asbäb al-nužul dan naskb;

2. Metode-metode dan teori penafsiran telah berkembang dalam tradisi Islam yang termanifestasikan dalam kajian ilmu tafsir; dan

3. Adanya berbagai mazhab tafsir, misalnya Syi’i, Mu'tazili, Sunni, dan sebagainya, mengindikasikan adanya pengaruh ideologis dan subyektifitas penafsir dalam proses penafsiran.

Penggunaan hermeneutika dalam mendekati teks al-Qur'an, menurutnya, akan menimbulkan beberapa kesulitan bagi keilmuan Islam tradisional: ${ }^{24}$

1. Signifikansi konteks dan peran manusia dalam penemuan makna mengimplikasikan bahwa al-Qur'an bukanlah teks yang berada diluar konteks sosio-historis, melainkan ada dalam konteks kemanusiaan yang kongkrit. Dengan kata lain, tanpa konteks, teks menjadi tidak bermakna. Preposisi ini tentu bertentangan

${ }^{2}$ Untuk penjelasan lebih lanjut lihat, Hans-George Gadamer, Kebenaran dan Metode, terj.Ahmad Sahidah (Yogyakarta: Pustaka Pelajar, 2004), hal. 334-369.

${ }^{23}$ Essack, Qur'an, hal. 61.

${ }^{24}$ Ibid., hal. 62-63. 


\section{Elya Munfarida}

dengan pandangan tradisional bahwa makna sebenarnya dari ayatayat al-Qur'an adalah apa yang dimaksudkan oleh Tuhan.

2. Penekanan pada agen manusia dalam produksi makna sangat kontradiksi dengan ide, bahwa Tuhan dapat memberikan manusia pemahaman yang benar, atau apa yang disebut oleh Arkoun sebagai konsep rasionalitas yang esensialis dan yang tidak dapat berubah, di mana intelek ketuhanan akan menjaga dan menjamin kebenaran pemahamannya.

3. Ulama tradisional telah membuat pembedaan yang ketat antara produksi kitab suci, di satu sisi, dan penafsiran dan resepsi di sisi lain. Distingsi ini merupakan faktor krusial dalam pembentukan hermeneutika al-Qur'an, yang akan berakibat pada pandangan bahwa hanya model hermeneutika Islam yang bisa mengatasi persoalan penafsiran al-Qur'an.

Ketidakpuasannya terhadap model penafsiran ulama tradisional (konservatif) yang dianggap tidak mampu menjadi basis teologis praksis bagi konteks diskriminasi dan ekploitasi yang melanda Afrika Selatan, mendorongnya mencari model hermenutika lain yang lebih mampu mengakomodir realitas sosial masyarakatnya. Model interpretasi tradisional yang cenderung memapankan idealitas tradisi ortodoksi dengan selalu mengembalikan otoritas kebenaran interpretasinya pada penafsiran salaf justru menimbulkan sikap mementingkan kesalehan dan keselamatan individual. Sikap asketis ini pada gilirannya membentuk sikap dan perilaku politik yang pasif di hadapan kebijakan-kebijakan struktural yang menindas dan yang secara implisit mendukung kemapanannya.

Pencariannya pada akhirnya berujung pada model hermenutika resepsi. Hermenutika ini berakar dari teori resepsi yang merupakan salah satu teori penting dalam tradisi postrukturalisme. ${ }^{25}$ Teori resepsi

${ }^{25}$ Teori lain yang dikategorikan sebagai teori postrukturalisme adalah teori resepsi sastra, teori interteks, teori feminis, teori poskolonial, teori dekonstruksi, dan teori wacana dan teks. Penjelasan lebih jauh tentang teori-teori tersebut serta sejarah kemunculan teori postrukturalisme dapat dilihat, Nyoman Kutha Ratna, Teori, Metode, dan Teknik Penelitian 
ini menyoroti soal bagaimana pembaca memberikan makna terhadap teks yang dibacanya, sehingga memberikan reaksi atau tanggapan terhadapnya. Tanggapannya ini bisa bersifat pasif, yakni bagaimana seorang pembaca dapat memahami karya itu, atau dapat melihat hakikat estetika yang ada di dalamnya, dan bisa juga aktif, yakni bagaimana pembaca merealisasikannya. Pendekatan ini melampaui kemapanan pendekatan-pendekatan yang sudah ada, yang lebih memfokuskan perhatian pada teks dan penulis semata atau proses terbentuknya teks oleh penulis (estetika produksi). Sementara dalam pedekatan resepsi, makna dilihat sebagai hasil interaksi teks dengan pembaca, tergantung bagaimana faktor-faktor posisi, kehadiran dan penerimaan sebuah teks oleh pembaca. ${ }^{26}$ Dengan demikian, teori ini menandai adanya pergeseran dominasi pengarang dalam menentukan makna sebuah teks ke pihak pembaca sebagai subyek yang membaca,

Sastra dari Strukturulisme bingga Postrukturalisme, (Yogyakarta: Pustaka Pelajar, 2006), hal. 143-295. Teori postrukturalisme memiliki banyak kesamaan teori posmodernisme, bahkan hampir identik karena tokoh-tokoh yang dikategorikan tokoh postrukturalisme juga dimasukkan sebagai tokoh-tokoh posmodernisme. Selain itu, kecenderungan mengangap realitas sosial sebagai tanda atau fenomena bahasa mengandaikan dapat diterapkannya teori bahasa dalam mengkaji realitas sosial, sehingga kedua teori tersebut saling mempengaruhi satu sama lain. Yasraf Amir Piliang, misalnya, memaparkan teori-teori yang berkembang dalam diskursus posmodernisme yang meliputi: matinya pengarang (dominasi pembaca/ resepsi), intertekstualitas, dekonstruksi, simulasi dan hiperealitas. Beberapa buku yang memberikan deskripsi manifestasi kultural kedua teori di atas dapat dilihat dalam Yasraf Amir Piliang, Hipersemiotika: Tafsir Cultural Studies Atas Matinya Makna (Yogyakarta: Jalasutra, 2003); Dunia Yang Dilipat: Tamasya Melampaui Batas-batas Kebudayaan (Yogyakarta: Jalasutra, 2004); dan Transpolitika: Dinamika Politik di Dalam Era Virtualitas (Yogyakarta: Jalasutra, 2005).

${ }^{26}$ Ahmad Baso, "Al-Qur'an dan Komunitas Agama sebagai "Pembaca ", dalam kata pengantar Ali Nurdin, Qur'anic Society: Menelusuri Konsep Ideal dalam Al-Qur'an, Jakarta: Erlangga, 2006). Pendekatan ini juga tercermin dalam karya Ahmad Baso yang lain, yakni Islam Pasca-Kolonial: Perselingkuhan Agama, Kolonialisme, dan Liberalisme, (Bandung: Mizan, 2005) dan NU Studies: Pergolakan Pemikiran antara Fundamentalisme Islam dan Fundamentalisme Neo-Liberal (Jakarta: Erlangga, 2006). Nyoman Kutha Ratna menyatakan bahwa teori resepsi ini muncul dengan beberapa pertimbangan: 1) sebagai jalan keluar untuk mengatasi strukturalisme yang hanya memberikan perhatian pada unsur-unsur; 2) timbulnya kesadaran untuk membangkitkan kembali nilai-nilai kemanusiaan dalam rangka kesadaran humanisme universal; 3) kesadaran bahwa nilai-nilai karya sastra dapat dikembangkan hanya melalui kompetensi pembaca; 4) kesadaran bahwa keabadian nilai karya seni disebabkan oleh pembaca; serta 5) kesadaran bahwa makna terkandung dalam hubungan ambiguitas antara karya sastra dan pembaca. Lihat Nyoman Kutha Ratna, Teori, hal. 166. 


\section{Elya Munfarida}

memahami dan merealisasikan teks tersebut atau pergeseran dari model estetika produksi ke estetika resepsi.

Teori ini kemudian dikembangkan menjadi salah satu bentuk hermeneutika yang memfokuskan pada proses penafsiran dari individu-individu atau kelompok-kelompok terhadap teks. Penafsiran ini, menurut Francis Schussler-Fiorenza, perlu mempertimbangkan tidak hanya teks dan penerima aslinya tapi juga transformasi antar horizon masa lampau dan horizon masa kini. Dengan demikian, hermeneutika ini memasukkan dua hal dalam proses penafsiran, yakni problem pergeseran horizon dari audiens yang berbeda dan transformasi horizon ekspektasi (harapan) masa lampau dan masa sekarang. ${ }^{27}$

Berdasarkan kerangka teoritik diatas, Farid Essack mengungkapkan tiga elemen penting dalam proses pemahaman teks. Ketiga unsur tersebut adalah teks dan pengarangnya, penafsir, dan tindak penafsiran. Pertama, persoalan teks al-Qur'an yang dikarang oleh Tuhan merupakan hal yang problematik. Di satu sisi, orang muslim mengklaim bahwa manusia tidak dapat mengetahui pikiran Tuhan, namun di sisi lain muncul klaim bahwa Tuhan telah mengontrol pikiran manusia yang memungkinkannya mendapatkan kebenaran yang diintensikan Tuhan. Kecenderungan ini terlihat dalam khazanah tafsir tradisional yang menolak pandangan bahwa penafsir dapat masuk dalam pikiran Tuhan, tetapi penolakan ini didasari bahwa interpretasinya itu adalah makna yang dimaksudkan Tuhan. Persoalan ini akan berakibat serius ketika akan diterapkan dalam wilayah sosial politik, karena identifikasi dengan pengarang atau penerima teks awal seringkali tidak mempertimbangkan perbedaan situasi historis antara penerima teks dan penafsir. Selain itu, klaim-klaim religiopolitis yang essensialis dan absolutis yang menganggap bahwa Tuhan telah memberi inspirasi penafsiran yang benar kepada penafsir, seringkali menimbulkan klaim-klaim kebenaran absolut dan menjadi tidak kondusif bagi pencarian pluralisme. ${ }^{28}$

\footnotetext{
${ }^{27}$ Essack, Qur'an, hal. 52.

${ }^{28}$ Ibid., hal. 74-75.
} 
Pandangan Essack ini menyiratkan bahwa manusia tidak dapat mengklaim penafsirannya sebagai "makna Tuhan”, namun "makna Tuhan" dapat ditangkap dalam dialektika teks dengan tuntutan dan kebutuhan historis penerimanya. Identifikasi historisitas penerima akan mengungkapkan peran fungsional dari realitas penerima yang memunculkan sebuah teks, yang kemudian peran tersebut ditransformasikan dalam konteks kekinian. Dalam hal ini, Essack mengintrodusir metodologi regresif-progresif yang ditawarkan Arkoun. Metode ini merupakan sebuah metode pembalikan terus menerus ke masa lalu, bukan untuk memproyeksikan tuntutan dan kebutuhan sekarang atas teks-teks fundamental itu, tetapi menemukan mekanisme dan faktor-faktor historis yang melahirkan teks-teks tersebut dan memberikan fungsi-fungsi tersebut kepadanya (prosedur regresif). ${ }^{29}$

Kedua, penafsir memiliki 'pra-paham' dan 'pra-suposisi' yang akan dibawanya ketika berinteraksi dengan teks. Pemaknaan sebuah teks oleh penafsir, disituasikan oleh subyektifitas, ekspektasi, dan situasi historis yang melingkupinya. Oleh karenanya, setiap penafsiran atau penerimaan, selalu bersifat parsial. "Tidak ada penafsiran yang murni, tidak ada penafsir murni, tidak ada teks yang murni”, ungkap Tracy. ${ }^{30}$

Ketiga, penafsiran tidak dapat terlepas dari bahasa, sejarah, dan tradisi. Bahasa merefleksikan sejarah dan tradisi penggunanya. Setiap tindak penafsiran adalah sebuah partisipasi dalam proses linguistik historis, pembentukan tradisi dan partisipasi ini muncul dalam ruang dan waktu. Oleh karenanya, interaksi dengan al-Qur'an juga melibatkan faktor-faktor bahasa, kultur, dan tradisi pembaca. ${ }^{31}$

${ }^{29}$ Mohammed Arkoun, Rethinking Islam (Washington, D.C.: Center for Contemporary Arab Studies, 1987), hal. 7.

${ }^{30}$ Essack, Qur'an, hal. 75.

${ }^{31}$ Ibid., hal. 76. 


\section{E. Al-Qur'an Sebagai Wahyu Progressif: Dasar Reinterpretasi Islam di Afrika Selatan}

Al-Qur'an merupakan manifestasi firman Allah yang bersifat universal, melampaui batas ruang dan waktu. Satatemen al-Qur'an yang menyatakan bahwa ia adalah petunjuk bagi manusia (al-baqarah: 2), mengindikasikan bahwa ajaran-ajaran yang terkandung di dalamnya dapat menjadi referensi umat Islam li kulli zamān wa maka $>n$. Hal ini berarti al-Qur'an dapat berdialog dengan realitas kemanusiaan dengan berbagai problem sosial yang dihadapi. Dengan demikian, universalitas al-Qur'an pada dasarnya terletak pada aplikasi normativitas ajaran-ajarannya pada dimensi historis panganutnya.

Realitas ini juga tergambar secara jelas dalam sejarah pewahyuan al-Qur'an. Kehendak Allah yang terwujud dalam ayatayat al-Qur'an, diturunkan sebagai respon atas kondisi sosial masyarakat penerimanya. Prinsip tadrij, di mana pewahyuan ajaranajaran al-Qur'an diturunkan secara bertahap, merefleksikan interaksi kreatif antara firman Allah, realitas sosio-kultural, serta kebutuhan masyarakat penerimanya. Interaksi ini merupakan sebuah keniscayaan, karena tindakan Tuhan dalam dunia adalah tindakan dalam ruang dan waktu yang terjadi melalui hukum-hukum alam itu sendiri baik alam fisik ataupun alam sosial. ${ }^{32}$ Dengan demikian, tindakan Tuhan, dalam hal ini wahyu al-Qur'an, akan dapat dipahami manusia jika wahyu itu berakar dari realitas kemanusiaan yang historis.

Al-Qur'an sendiri, menurut Essack, secara eksplisit menyebutkan alasan model pewahyuannya ini, yakni: ${ }^{33}$

1. Al-Qur'an hadir sebagai petunjuk day-to-day yang membutuhkan pola pewahyuan secara bertahap (17:106); dan

2. Islam eksis dalam situasi perjuangan dan Nabi Muhammad membutuhkan dukungan secara kontinyu dari interaksinya

${ }^{32}$ Nasr Hamid Abu Zayd, Mafbūm al-Nașs: Diräsah fi 'Ulüm al-Qur'an, (Beirut: alMarkaz al-Thaqäfi al-'Arabi, 1994), hal. 99.

${ }^{33}$ Essack, Qur'an, hal. 54-55. 
dengan al-Qur'an. Hal ini tergambar dalam respon al-Qur'an terhadap sikap para penentangnya yang mempertanyakan mengapa al-Qur'an tidak diturunkan sekaligus, dengan menjawabnya bahwa cara ini justru bertujuan untuk memantapkan hati penerimanya (25:32). "Pemantapan hati" yang disinggung dalam ayat di atas, sebagaimana dikatakan Ibnu Khaldun, mengindikasikan bahwa kondisi "penerima pertama" ikut dipertimbangkan, sebab proses komunikasi wahyu amat sulit diterima, minimal pada masa-masa awal. ${ }^{34}$

Prinsip wahyu progresif, yang dicirikan dengan proses pewahyuan secara gradual, secara jelas direpresentasikan dalam ilmu asbāb al-nuzul dan ilmu naskh. Ilmu asbāb al-nuzūl mengkaji sebabsebab atau peristiwa-peristiwa partikular yang menjadi alasan turunnya ayat. Asbāb al-nuzul ini ditransmisikan dari generasi ke generasi yang kemudian terkodifikasi dalam hadis, sehingga untuk mengetahuinya dapat ditelusuri melalui hadis Nabi SAW. Sebab-sebab turunnya wahyu dapat diklasifikasikan dalam dua bentuk yakni asbāb al-nu₹ūl mikro, yang menunjuk pada sebab khusus dari turunnya ayat; dan asbāb al-nuzūl makro yang menunjuk pada realitas sosial kultural masyarakat Arab saat itu. Signifikansi asbāb al-nuzūl makro tidak bisa diabaikan atau bahkan dinegasikan dalam proses penafsiran, karena sebuah bahasa merepresentasikan kebudayaan dan pemikiran masyarakat penggunanya. ${ }^{35}$ Oleh karenanya, produksi sebuah teks melalui media bahasa Arab, akan melibatkan tradisi dan pemikiran komunitas Arab. Kajian asbāb al-nu₹ūl baik mikro maupun makro menegaskan hubungan dan dialektika yang kreatif antara teks dan realitas yang melingkupinya.

Sementara naskh adalah pembatalan hukum, baik dengan menghapuskan dan melepaskan teks yang menunjuk hukum dari bacaan (tidak dimasukkan dalam kodifikasi al-Qur'an) atau membiarkan teks tersebut tetap ada sebagai petunjuk adanya hukum yang

\footnotetext{
${ }^{34}$ Ibid., hal. 98.

${ }^{35}$ Ibid., hal. 106.
}

Al Manāhij, Vol. 2 No. 1 Januari - Juni 2008 


\section{Elya Munfarida}

di-mansükh. Pembatalan teks ini tidak kemudian berarti ayat-ayat yang dibatalkan kehilangan fungsi legitimasinya, namun menurut Quraish Shihab, naskh lebih dimaknai sebagai tabdīl atau pergantian dari satu wadah ke wadah lain. Artinya semua ayat al-Qur'an tetap berlaku, tidak ada kontradiksi dan yang ada adalah pergantian hukum bagi masyarakat atau orang tertentu karena kondisi yang berbeda. ${ }^{36}$ Hal senada juga diungkapkan oleh Naṣr Ḥāmid Abū Zayd dengan menyatakan bahwa hukum-hukum syari'at adalah hukum-hukum yang diperuntukkan khusus kepada manusia dalam mengatur segala aktivitas mereka yang dinamis, karenanya hukum-hukum syari'at pun harus dinamis. ${ }^{37}$

Kedua konsep diatas, asbāb al-nuzūl dan naskh, menyingkapkan adanya hubungan yang sangat erat antara teks dan realitas. Dialektika kedua elemen ini, bagi Essack, menjadi dasar bagi reinterpretasi teks sesuai dengan kebutuhan dan tuntunan kontemporer dengan mengkontekstualisasikan pesan-pesan di dalamnya dan menangkap kembali "wilayah-wilayah yang tak dipikirkan" (unthinkable territory) yang semakin meluas dalam pemikiran Islam. Pertautan penguasa dan ulama dalam relasi kekuasaan dalam sejarah peradaban Islam, berperan mereduksi atau bahkan mengeliminar dimensi transformatif Islam demi mempertahankan kekuasaannya. Dalam konteks ini, "wilayah-wilayah tak dipikirkan" dikonstruksi oleh kekuasaan tertentu untuk melanggengkan otoritasnya, baik yang bersifat profan maupun religius. ${ }^{38}$ Dengan menggunakan perspektif Foucoult, kekuasaan memproduksi kebenaran yang kemudian, meminjam bahasa Louis Althusser, diinterpelasi/diterima subyek komunitas

${ }^{36}$ M. Quraish Shihab, Membumikan Al-Qur'an (Bandung: Mizan, 1994), hal.146.

${ }^{37}$ Abū Zayd, Mafbūm al-Nașs, hal.146.

${ }^{38}$ Relasi kekuasaan dalam wacana keagamaan menyingkapkan konsep yang terpikir, yang tak terpikir dan yang tak dipikirkan dalam pemikira Islam. Yang terpikir merepresentasikan konsep yang dikenal oleh İslam, sementara yang tak terpikir merupakan konsep-konsep yang asing atau tidak dikenal dalam Islam. Yang tak dipikirkan adalah konsep yang dikenal tapi tidak dipikirkan baik karena tidak disadari signifikansinya ataupun 'disadari' tapi tidak dipikirkan demi mempertahankan ortodoksi. Elaborasi lebih jauh tentang konsep ini lihat Mohammed Arkoun, Kajian Kontemporer Al-Qur'an (Bandung: Penerbit Pustaka, 1998), hal. 12-42. 
Islam, sehingga menjadi "kebenaran" itu sendiri yang tidak lagi dipertanyakan dan tak terbantahkan kebenarannya.

\section{F. Konsep-konsep Kunci sebagai Dasar Pemahaman Al- Qur'an dalam Konteks Afrika Selatan}

Adanya pertimbangan situasi historis penafsir (pembaca) dalam penafsiran al-Qur'an, akan menimbulkan hadirnya subyektivitas, ideologi dan kepentingan penafsir ketika berdialog dengan teks. 'Prapaham' dan ekspektasi yang diharapkan seorang pembaca diperoleh legitimasinya dari teks, selain memiliki peran produktif dalam pemaknaan, juga berperan membawa teks untuk melegitimasi 'prasuposisi' dan ekspektasinya, sehingga teks hadir dalam cara di mana penafsir menginginkannya. Kondisi ini akan berpotensi menjustifikasi tafsir-tafsir ideologis yang cenderung memihak kepentingan masingmasing kelompok dan mengeksklusi kelompok-kelompok lain.

Farid Essack menyadari konsekuensi dari pengaruh subyektivitas penafsir. Untuk itu, ia meletakkan beberapa konsep kunci sebagai landasan penafsiran teks yang 'subyektif tapi obyektif'. Konsep-konsep tersebut adalah:

\section{Taqwā}

Taqwā dalam al-Qur'an digunakan dalam berbagai pengertian baik dalam konteks realsi dengan Allah maupun realsi dengan manusia. Al-Qur'an menghubungkan taqwä dengan beriman kepada Allah $(10: 63 ; 27: 53,41 ; 83)$ dan menganggapnya sebagai pencapain tertinggi dalam beribadah kepada Allah (2:21). Orang-orang yang memilih keuntungan-keuntungan jangka pendek di dunia dikontraskan dengan taqwa $(4: 77,6: 32,12: 57)$. Dalam konteks kemanusiaan, taqwa dihubungkan dengan interaksi sosial dan perhatian terhadap yang lain, kesediaan berbagi (92:5, 7:152-3), memenuhi janji (3:76; 7:52) dan terutama memberikan kebaikan (3:172; 4:126; 5:93; 16:127). Selain itu, al-Qur'an juga menekankan pentingnya taqwa dalam komunitas dan individu yang akan mengemban tugas transformasi dan liberasi $(3: 102-5,125 ; 8: 29)$. Menurut al-Qur'an, 


\section{Elya Munfarida}

komitmen terhadap manusia merupakan bagian tak terpisahkan dari kominten terhadap Tuhan.

Penerimaan taqwā sebagai kunci hermeneutik akan memiliki implikasi signifikan bagi penafsir dan tindak penafsirannya. Pertama, taqwa akan menghindarkan penafsiran dari obskurantisme teologis dan reaksi teologis, serta dari spekulasi individual yang sangat subyektif, bahkan meski penafsir berasal dari kaum yang tertindas. Kedua, taqwa dapat memfasilitasi keseimbangan estetik dan spiritual dalam kehidupan penafsir. Ketiga, taqwā dapat memberikan komitmen bagi penafsir sebuah proses personal dan transformasi sosial politik yang dialektis. Keempat, bagi aktivis sebagai penafsir, taqwā akan mencegah dia menjadi imaje dari tirani yang ditentangnya. ${ }^{39}$

\section{Tawhìi}

Konsep tawbid yang bermakna keesaan Tuhan, tidak ada yang menyamainya, merupakan dasar, pusat dan akhir dari tradisi Islam. Komprehensifitas dan holisme Islam berakar dari konsep ini. Keyakinan bahwa tawh\}id merupakan jantung worldview sosial politik, telah mendorong beberapa pemikir, seperti Ali Syari'ati, Mujahidin Iran, Hasan Hanafi, serta pemikir lainnya, untuk merealisasikan keesaan Tuhan dalam relasi-relasi kemanusiaan dan sistem sosioekonomi.

Dalam konteks Afrika Selatan, tawbid mempunyai dua aplikasi spesifik, yakni pada tataran eksistensial tawḅid bermakna penolakan terhadap konsepsi eksistensi manusia yang dualistik melalui dikotomi sekuler dan spiritual, sakral dan profan; dan pada tataran politis, tawhìid berarti penolakan terhadap pembagian sosial yang didasarkan pada ras dan etnik, karena keesaan Tuhan merefleksikan kesatuan umat manusia sebagai makhluk-Nya. ${ }^{40}$ Dalam konstruksi hermenutika pembebasan al-Qur'an, konsep tawbịid menjadi dasar penolakan

\footnotetext{
${ }^{39}$ Essack, Qur'an, hal. 87-90.

${ }^{40}$ Ibid., hal. 92.
} 
diskursus yang didasarkan pada syirik, yakni penggunaan teologi yang dipisahkan dari analisis sosial.

\section{Al-Nās}

Al-Näs dalam al-Qur'an digunakan untuk menunjukkan kolektifitas sosial, di mana, menruut Ali Syari'ati, manusia ditempatkan secara harmonis bersama dengan Tuhan dan alam dalam dunia tawbìi. Sentralitas manusia di dunia direfleksikan dalam penunjukannya sebagai khalifah Tuhan di bumi ini (15:29; 32:9; 38:72). Hal ini menimbulkan dua implikasi hermenutik: pertama, al-Qur'an harus ditafsirkan dengan cara memberikan dukungan bagi kepentingan manusia secara keseluruhan atau kepentingan mayoritas, bukan interes minoritas. Kedua, interpretasi harus dibentuk oleh pengalaman dan aspirasi umat, yang seringkali berseberangan dengan aspirasi minoritas yang berkuasa. ${ }^{41}$

\section{Mustad'afuin}

Dalam al-Qur'an, mustad'afün merujuk pada orang-orang yang tertindas atau lemah atau orang-orang yang diperlakukan dengan cara yang arogan. Istilah-istilah arädzil (yang tertindas) (11:27, 26:70; 22:5), fuqarā' (fakir)(2:271; 9:60) dan masäkin (orang-orang miskin) $(2: 83,177 ; 4: 8)$, untuk mendeskripsikan kelas-kelas sosial yang lemah dan tertindas. ${ }^{42}$ Mereka semua adalah kelompok sosial yang harus dibebaskan dari keterbatasan dan belenggu penindasan. Tugas ini telah direalisasikan oleh Nabi saw sepanjang kehidupannya, sehingga asketisme personal yang dijalani Nabi, tidak menghalanginya untuk melakukan berbagai transformasi sosial.

Preferensi Nabi saw. terhadap peningkatan harkat kemanusiaan mustad'afun, harus dijadikan pilihan penafsir dalam memahami teks dan menerapkannya dalam rangka perjuangan melawan ketidakadilan

\footnotetext{
${ }^{41}$ Ibid., hal. 96.

${ }^{42}$ Ibid., hal. 98.
} 


\section{Elya Munfarida}

dan pembebasan kaum tertindas. Dalam konteks Afrika Selatan, konsep ini dijadikan sebagai landasan untuk mencari kontribusi alQur'an terhadap perjuangan untuk memperoleh keadilan bagi masyarakat Afrika Selatan yang mayoritas termasuk kaum mustad'afun dan sebagian para pejuangnya adalah orang-orang non Islam. ${ }^{43}$

\section{Qist dan 'Adl.}

Al-Qur'an menggunakan kedua istilah ini untuk menunjuk pada konsep keadilan. Qișt bermakna kesetaraan, keadilan, memberikan seseorang proporsinya. Sementara 'adl bermakna bertindak secara sama atau setara, secara adil, atau dengan benar. Al-Qur'an menekankan diterapkannya konsep keadilan dalam segala sesuatu, sehingga keadilan harus dijadikan dasar relasi sosial dan kehidupan manusia dalam bidang apapun. Keadilan akan menciptakan tatanan sosial yang humanis, sementara ketidakadilan akan menciptakan kondisi sebaliknya, yakni tatanan sosial yang menyimpang, destruktif dan tidak humanis. ${ }^{44}$

Dalam sebuah realitas sosial yang tidak adil, konsep keadilan dalam al-Qur'an dapat dijadikan basis ideologis untuk menentang ketidakadilan dengan segala manifestasinya. Hal ini akan memunculkan dua implikasi penting: pertama, penafsir yang berada dalam situasi opresi, dapat menjustifikasi penggunaan pendekatan obyektif terhadap al-Qur'an, selama ia mencari cara bagaimana alQur'an bisa digunakan untuk melawan ketidakadilan yang membelenggu masyarakatnya. Kedua, pendekatan terhadap al-Qur'an sebagai alat perlawanan mengasumsikan diterimanya semua komitmen-komitmen teologis dan ideologis serta afinitas terhadap nilai-nilai di atas. ${ }^{45}$ Nilai-nilai tersebut direalisasaikan dalam perjuangan melawan status quo yang opresif, dan bersama-sama dengan masyarakat dan kaum tertindas menciptakan tatanan sosial yang adil.

\footnotetext{
${ }^{43}$ Ibid., hal. 103.

${ }^{44}$ Ibid., hal. 103-104.

${ }^{45}$ Ibid., hal. 106.
} 


\section{Jihād}

Jihäd secara literal bermakna berjuang, berusaha sekuat tenaga. Istilah digunakan dalam al-Qur'an baik dalam berjuang untuk berperang maupun berjuang dalam konteks lebih luas, yakni transformasi diri dan lingkungan sosial. Essack memaknai jihad sebagai "perjuangan dan praksis". Dengan mengutip pendapat Rebecca Chopp, Essack mendefinisikan praksis sebagai "sebuah tindakan sadar yang diambil oleh sebuah komunitas yang memiliki tanggung jawab atas determinasi politisnya, yang didasari oleh pandangan bahwa manusialah yang membuat sejarah". ${ }^{46}$ Dalam kondisi sosial A frika Selatan yang mengalami berbagai bentuk penindasan, jihad sebagai tindakan praksis menciptakan kerangka ideologis bagi perjuangan umat Islam, bersama dengan umat non Islam, untuk berpartisipasi secara aktif dalam wilayah politik praktis guna menentang struktur sosial politik yang opresif.

Dari aspek tindak hermeneutik, dua konsep pertama, taqwā dan tawbid, bertujuan mengembangkan kriteria moral dan doktrin dalam berdialog dengan teks. Dua konsep kedua, al-nās dan mustad'afun, menunjukkan lokasi aktivitas penafsiran. Sementara, dua konsep terakhir, qist dan 'adl serta jihäd, merefleksikan etos dan metode memproduksi dan membentuk pemahaman yang kontekstual terhadap firman Tuhan dalam masyarakat yang tidak adil. Keenam konsep dasar di atas, merupakan pedoman bagi penafsir atau pembaca dalam berdialog dengan teks, sehingga subyektivitas, ekspketasi dan ideologinya tidak mendorongnya untuk keluar dari batas-batas penafsiran obyektif. Aplikasi konsep-konsep kunci tersebut, akan memampukan penafsir mendapatkan penafsiran yang tepat dan obyektif sesuai dengan tuntutan dan kebutuhan sosial masyarakatnya, sehingga dapat menciptakan berbagai transformasi sosial seperti tercermin dalam sejarah kehidupan Nabi saw.

\footnotetext{
46 Ibid., hal. 107.
} 


\section{Elya Munfarida}

\section{G. Kesimpulan}

Dialektika al-Qur'an sebagai teks dan realitas penerimanya sebagai konteks, merepresentasikan sisi historisitas al-Qur'an dalam sejarah kemanusiaan. Dialektika ini seringkali kurang mendapatkan perhatian yang intens dari para intelektual Islam, sehingga mendorong sakralisasi teks yang menghambat kreatifitas penafsiran. Akibat selanjutanya, dimensi transformatif yang mengiringi historisitas teks, juga termarginalisasi, sehingga fungsi transformatif teks kehilangan eksistensinya.

Hilangnya sisi historisitas teks ini juga dirasakan Farid Essack dalam diskursus keilmuan Islam. Kondisi ini mendorongnya mengadopsi hermenutika resepsi sebagai metode penafsiran yang tidak hanya mampu mengakomodir dimensi historis teks, tapi juga memberikan ruang bagi komunitas agama sebagai pembaca untuk berdialog dengan teks sesuai dengan kondisi sosial yang melingkupinya. Pendekatan ini cocok untuk diterapkan dalam konteks sosial Afrika Selatan. Dengan adanya penindasan, rasisme dan ekploitasi ekonomi, al-Qur'an diharapkan mampu memberi landasan teologis praksis bagi perjuangan untuk memperoleh kebebasan. Pendekatan ini diaplikasikan dengan menjadikan konsep-konsep dasar dalam alQur'an sebagai pedoman untuk mendapatkan penafsiran yang obyektif sesuai dengan konteks Afrika Selatan.

\section{DAFTAR PUSTAKA}

Abdurrahman, Moeslim. Islam Yang Memihak. Yogyakarta: LkiS, 2005. Abu Zayd, Nasr Hamid.. Mafbum an-Nash: Dirasah fi Ulum al-Qur'an. Beirut: al-Markaz as-Saqafi al-'Arabi, 1994.

Arkoun, Mohammed.. Kajian Kontemporer Al-Qur'an. Bandung: Penerbit Pustaka, 1998.

. Rethinking Islam. Washington, D.C.: Center for Contemporary Arab Studies, 1987. 
Hermeneutika Al-qur'an dalam Perspektif Farid Essack

Baso, Ahmad. NU Studies: Pergolakan Pemikiran antara Fundamentalisme Islam dan Fundamentalisme Neo-Liberal. Jakarta: Erlangga, 2006.

. "Al-Qur'an dan Komunitas Agama sebagai "Pembaca “, dalam kata pengantar Ali Nurdin, Qur'anic Society: Menelusuri Konsep Ideal dalam Al-Qur'an, Jakarta: Erlangga, 2006.

. Islam Pasca-Kolonial: Perselingkuban Agama, Kolonialisme, dan Liberalisme. Bandung: Mizan, 2005.

Enggineer, Asghar Ali. Islam dan Teologi Pembebasan, terj. Agung Prihantoro. Yogyakarta: Pustaka Pelajar, 1999.

Essack, Farid. On Being A Muslim: Menjadi Muslim Di Dunia Modern. Terj. Dadi Darmadi \& Jajang Jahroni. Jakarta: Erlangga, 1977.

- Qur'an, Liberation \& Pluralism: an Islamic Perspectives of Interreligious Solidarity Against Oppression. England: Oneworld, 1977.

Gadamer, Hans-George. Kebenaran dan Metode, terj. Ahmad Sahidah. Yogyakarta: Pustaka Pelajar, 2004.

Hidayat, Komaruddin. Memahami Bahasa Agama. Jakarta: Paramadina, 1996.

Karim, Khalil Abdul. Syari'ab: Sejarah Perkelabian Pemaknaan. Yogyakarta: LKiS, 2003.

- Hegemoni Quraisy: Agama, Budaya, Kekuasaan. Yogyakarta: LKiS, 2002.

-. Negara Madinab: Politik Penaklukan Masyarakat Suku Arab. Yogyakarta: LKiS, 2005.

Moosa, Ebrahim. "Muslim Conservatism in South Africa." In Journal of Theology for Southern Africa 69 (December 1989), p.7677 , yang diakses di http://web.uct.ac.za/depts/ricsa/ tre/j69moosa.htm, pada tanggal 20 July 2007.

Piliang, Yasraf Amir. Dunia Yang Dilipat: Tamasya Melampaui Batas- 
Elya Munfarida

batas Kebudayaan. Yogyakarta: Jalasutra, 2004.

. Hipersemiotika: Tafsir Cultural Studies Atas Matinya Makna, Yogyakarta: Jalasutra, 2003.

- Transpolitika: Dinamika Politik di Dalam Era Virtualitas. Yogyakarta: Jalasutra, 2005.

Ratna, Nyoman Kutha. Teori, Metode, dan Teknik Penelitian Sastra dari

Strukturalisme bingga Postrukturalisme. Yogyakarta: Pustaka Pelajar, 2006.

Shihab, M. Quraish. Membumikan Al-Qur'an. Bandung: Mizan, 1994.

Smith, Wilfred Cantwell. The Meaning and End of Religion. Minneapolis: Fortress Press, 1991. 